\title{
Does plant architectural complexity increase with increasing habitat complexity? A test with a pioneer shrub in the Brazilian Cerrado
}

\author{
Silveira, FAO. ${ }^{a *}$ and Oliveira, EG. ${ }^{b}$ \\ aDepartamento de Botânica, Universidade Federal de Minas Gerais - UFMG, Av. Antônio Carlos, 6627, \\ CEP 30161-970, Belo Horizonte, MG, Brazil \\ 'Instituto de Ciências Biológicas e da Saúde, Centro Universitário Una, Campus Guajajaras, \\ CEP 30180-100, Belo Horizonte, MG, Brazil \\ *e-mail: faosilveira@gmail.com
}

Received May 17, 2012 - Accepted June 15, 2012 - Distributed May 31, 2013

(With 1 figure)

\begin{abstract}
Understanding variation in plant traits in heterogeneous habitats is important to predict responses to changing environments, but trait-environment associations are poorly known along ecological gradients. We tested the hypothesis that plant architectural complexity increases with habitat complexity along a soil fertility gradient in a Cerrado (Neotropical savanna) area in southeastern Brazil. Plant architecture and productivity (estimated as the total number of healthy infructescences) of Miconia albicans (SW.) Triana were examined in three types of vegetation which together form a natural gradient of increasing soil fertility, tree density and canopy cover: grasslands (campo sujo, CS), shrublands (cerrado sensu strico, CE) and woodlands (cerradão, CD). As expected, plants growing at the CS were shorter and had a lower branching pattern, whereas plants at the CD were the tallest. Unexpectedly, however, CD plants did not show higher architectural complexity compared to CE plants. Higher architectural similarity between CE and CD plants compared to similarity between CS and CE plants suggests reduced expression of functional architectural traits under shade. Plants growing at the CE produced more quaternary shoots, leading to a larger number of infructescences. This higher plant productivity in CE indicates that trait variation in ecological gradients is more complex than previously thought. Nematode-induced galls accounted for fruit destruction in $76.5 \%$ infructescences across physiognomies, but percentage of attack was poorly related to architectural variables. Our data suggest shade-induced limitation in M. albicans architecture, and point to complex phenotypic variation in heterogeneous habitats in Neotropical savannas.
\end{abstract}

Keywords: Cerrado, plant architecture, nematode galls, shade tolerance, trait-environment association.

\section{A complexidade arquitetural de plantas aumenta com a complexidade do habitat? Um teste com um arbusto pioneiro de Cerrado}

\begin{abstract}
Resumo
O entendimento da variação dos atributos de plantas em ambientes heterogêneos é importante para prever respostas às mudanças climáticas; entretanto, a resposta de atributos das plantas às mudanças ambientais é pouco conhecida ao longo de gradientes ecológicos. Testou-se a hipótese de que a complexidade arquitetural de Miconia albicans (SW.) Triana aumenta com a complexidade ambiental, ao longo de um gradiente de fertilidade de solo em um Cerrado no sudeste brasileiro. A arquitetura e a produtividade (estimada por meio do número total de infrutescências sadias) foram examinadas em três tipos de vegetação, que formam um gradiente de fertilidade de solo, de densidade de árvores e de cobertura vegetal: campo sujo (CS), cerrado sensu stricto (CE) e cerradão (CD). Plantas crescendo no CS foram menores e apresentaram menor complexidade arquitetural, enquanto plantas no CD foram maiores. No entanto, de forma inesperada, plantas no CD não demonstraram maior complexidade arquitetural quando comparadas às plantas de $\mathrm{CE}$, e a maior similaridade arquitetural entre plantas de CE e CD, quando comparadas com plantas de CE e CS, sugere que a expressão de atributos funcionais da arquitetura é limitada sob condições de sombra. Plantas de CE produziram mais ramos quaternários e maior número de infrutescências, sendo que a maior produtividade destas plantas indica que a variação de atributos em gradientes ecológicos é mais complexa do que se pensava anteriormente. Galhas de nematóides destruíram 76,5\% das infrutescências nas vegetações, mas a porcentagem de ataque não esteve fortemente correlacionada com as variáveis arquiteturais. Os resultados do presente trabalho sugerem limitação na expressão da arquitetura da planta induzida pela sombra e apontam para uma complexa variação fenotípica na colonização de ambientes heterogêneos de savanas neotropicais.
\end{abstract}

Palavras-chave: Cerrado, arquitetura de planta, galhas de nematoide, tolerância à sombra, associação traço-ambiente. 


\section{Introduction}

Phenotypic variation plays a central role in plant evolutionary biology, yet it is a poorly known subject (Hallgrimson and Hall, 2005). Intraspecific variation in plant morphology and functional traits arise from phenotypic plasticity and/or genetic differentiation among ecotypes (Pil et al., 2012). There is a growing consensus that phenotypic variation has an important role for plants to cope with environmental heterogeneity in time and space, especially in heterogeneous habitats (Valladares et al., 2006, 2007). Therefore, studies addressing phenotypic variation can improve our understanding of plant responses to changing environments.

The Brazilian Cerrado is a spatially heterogeneous Neotropical savanna. The Cerrado vegetation consists of a mosaic of different physiognomies, which vary in the relative dominance of herbaceous versus woody vegetation (Oliveira-Filho and Ratter, 2002). Such a complex mosaic is controlled by climate, soil physical and chemical properties and fire regime, in a way that physiognomies ranging from grasslands to woodlands exhibit contrasting environmental conditions (Oliveira-Filho and Ratter, 2002). Few Cerrado species are distributed over the range of physiognomies (Mendonça et al., 2008), because many are seed limited (Salazar et al., 2012) and because some may not be able to cope with variation in environmental conditions. Recent studies have shown that several Cerrado species have a complex intraspecific variation in functional and morphological traits (Pedroso et al., 2010). Intraspecific variation may maximise resource capture (Grime and Mackey, 2002), which potentially contribute to the colonisation of heterogeneous habitats. To date, most studies addressing intraspecific variation in plant traits of Cerrado species have focused on comparison of individuals occurring in habitats with two opposing environmental conditions, such as open versus shaded (Rossatto and Kolb, 2010) or dry versus flooded physiognomies (Somavilla and Graciano-Ribeiro, 2011). The patchy distribution of Cerrado physiognomies makes such a dichotomous distribution unrealistic, so knowledge on trait variation along ecological gradients is especially important for a better understanding of trait-environment associations in the Cerrado (Bedetti et al., 2011).

Plant architecture plays a central role in functional plant ecology (Valladares and Niinemets, 2007). Though the functional significance of crown architecture attributes is not fully understood, its role in contributing to shade tolerance is becoming apparent in the last years (Valladares and Niinemets, 2008). Plant architecture traits are related to temperature regulation and light interception, and ultimately affect photosynthetic efficiency and plant growth (Cui et al., 2003; Pearcy et al., 2004; Sarlikioti et al., 2011). Plant architecture also influences plant biomechanical properties and population ecology (Barthelemy and Caraglio, 2007). Variation in plant architecture has further ecological implications. Variation in crown architecture strongly affects the community of insect herbivores and their predators (Lawton, 1983; Casas and Djemai, 2002), and the inflorescence architecture also influences pollination ecology (Barthelemy and Caraglio, 2007). Both biotic and abiotic pressures modulate the evolution of plant architecture, so that ontogenetic shifts in plant architecture represent a balance between deterministic genetic and opportunistic responses to stochastic environmental events (Sussex and Kerk, 2001; Weiner, 2004). To our knowledge, no study has examined the patterns of trait variation in plant architecture along an ecological gradient.

Here, we report changes in plant architectural traits in a pioneer shrub along a soil fertility gradient in the Brazilian Cerrado. Our study species, Miconia albicans (SW.) Triana (Melastomataceae), is an evergreen widespread shrub, abundant in several Cerrado physiognomies, and therefore is an adequate model organism for testing traitenvironment associations (Bedetti et al., 2011). Specifically, we expect the components of plant architecture, plant size and architectural complexity, to increase with increasing habitat complexity. We also expect an increase in plant productivity with increasing habitat complexity if productivity and architecture are correlated.

\section{Material and Methods}

Study site and species - This study was performed at the Estação Ecológica de Pirapitinga (EEP), Três Marias, Minas Gerais, in southeastern Brazil. The EEP is an artificial island created as the result of the flooding of the Três Marias reservoir in 1965 (from $18^{\circ} 20.09^{\prime} \mathrm{S}$ to $18^{\circ}$ $23.15^{\prime} \mathrm{S}$ and $45^{\circ} 17.4^{\prime} \mathrm{W}$ to $45^{\circ} 20.51^{\prime} \mathrm{W}$ ). The EEP is located about $600 \mathrm{~m}$ above sea level. The climate is seasonal with well-defined rainy (from October to March) and dry (April-September) seasons. The mean annual temperature ranges from 21 to $25^{\circ} \mathrm{C}$ and the average annual precipitation is nearly $1200 \mathrm{~mm}$ (Bedetti et al., 2011). The vegetation of the EEP consists of campo sujo, cerrado sensu stricto and cerradão. Soil fertility, tree density and canopy cover all increase from campo sujo towards cerradão (CS $<\mathrm{CE}$ $<\mathrm{CD}$ ). The campo sujo (hereafter referred to as CS) is a nutrient-poor soil grassland with a continuous herbaceous layer and scattered small-sized shrubs and trees. The canopy cover is generally less than $5 \%$. The cerrado sensu stricto (hereafter referred to as CE) is characterised by sparsely distributed 3-8m tall shrubs and trees with nearly $30 \%$ canopy cover and considerable grass cover. The upper extreme of the gradient, the cerradão (hereafter referred to as $\mathrm{CD}$ ), is an almost closed woodland with canopy cover ranging from $50 \%$ to $90 \%$; 8 -12 $\mathrm{m}$ trees cast considerable shade, so that the grass layer is much reduced (OliveiraFilho and Ratter, 2002).

Miconia albicans is a widespread evergreen species in South America occurring from southeastern Brazil to Southern México (Goldenberg, 2004). It is a pioneer, occurring in disturbed habitats, forest edges, along roadsides and across several physiognomies of the Brazilian Cerrado. Its whitish, small and scentless flowers produce unviable pollen grains which are not visited by bees. Flowering 
occurs from August to October, and its bird-dispersed berries ripen at the onset of the rainy season and last until mid-rainy season (Silveira et al., 2012). In this species, the apomictic reproductive system strongly restricts gene flow (Renner, 1989; Goldenberg and Shepherd, 1998). Its leaves are simple, opposite, elliptic, with a pubescent whitish abaxial surface and are continuously produced yearround (Bedetti et al., 2011). Miconia albicans is the host of galls induced by Ditylenchus gallaeformans (Oliveira et al. 2013) (Nematoda). These nematode-induced galls occur in both leaves and reproductive structures, which potentially reduce plant productivity (Viana et al., 2013).

Sampling and statistics - This study was performed in December 2009, during the fruiting peak of M. albicans. We established a $500 \mathrm{~m}$-transect in each physiognomy where 20 individuals located within $2 \mathrm{~m}$ from either side of the transect were randomly selected. Total height ( $\mathrm{cm}$; up to the last node), height of first lateral shoot, total number of secondary, tertiary and quaternary shoots, and total number of infructescences were recorded for each individual.

Total number of healthy infructescences was used as an estimate of plant productivity. Because nematode-induced galls potentially decrease plant performance (Viana et al. 2013), fruits destroyed by Ditylenchus galls were also recorded. Each infructescence was classified into three categories: healthy $(\mathrm{H})$, partially damaged (PD), and totally damaged (TD). Healthy infructescences showed null or minor signs of leaf galls, and their fruits lacked Ditylenchus-induced galls. PD infructescences showed signs of galls in the pedicels and fruits, with at least one fruit completely destroyed by galls. TD infructescences showed extensive signs of galls in the infructescence and all fruits were entirely destroyed by Ditylenchus galls.

Previous to hypothesis-testing analysis, data were checked for assumptions of parametric statistics. In order to determine statistically significant differences in architectural parameters among physiognomies, we used one-way ANOVAs when data met those assumptions (errors normally distributed and homocedasticity). The Tukey test was used as a multiple comparison test. Data were log-transformed for height and quaternary shoot number. When data did not meet the assumptions of parametric analyses, a rank transformation was employed, and the Kruskal-Wallis test was used. Multiple comparisons were performed using the Conover test. A value of $\alpha=0.05$ was used for all analyses.

A principal component analysis (PCA) was carried out based on the correlation matrix of all architectural variables. We excluded the height of the first shoot from the PCA because it was not correlated with the other variables. The extent of variation in architectural traits related to physiognomies was determined using a quantitative estimate of phenotypic plasticity (Valladares et al., 2006). The lack of quantitative population genetic data prevented us from assigning phenotypic plasticity as the underlying mechanism of intraspecific variation (see Pil et al., 2012). Hence, the quantitative index used here estimates the morphological distance between plants growing in different physiognomies, rather than genetic identity of individuals (Valladares et al., 2006). The relative distance plasticity index (RDPI) measures the relative distances between values of architectural parameters measured for all pairs of individuals growing in different physiognomies. These distances were calculated according to the following formula (Valladares et al., 2006) (Equation 1):

$$
R D_{i j \rightarrow i j^{\prime}}=d_{i j \rightarrow i j^{\prime}} /\left(x_{i j^{\prime}}+x_{i j}\right)
$$

where $j$ and $j$ ' are individuals of the different physiognomies $i$ and $i$ '. RDPI varies from zero (no plasticity) to one (maximal plasticity) and was calculated according to the following formula (Equation 2):

$$
R D P I=\sum\left(d_{i j \rightarrow i^{\prime} j^{\prime}} /\left(x_{i^{\prime} j^{\prime}}+x_{i j}\right) / n\right.
$$

where $n$ is the total number of distances. For the calculation of RDPI, we randomly selected ten individuals from each physiognomy.

To test for the relationship of healthy, PD and TD infructescence number with architectural parameters, data were log-transformed and fit into a multiple stepwise regression analysis after checking for colinearity. Data for PD and TD were used as percentage. The full model (all architectural parameters included) was simplified by removing non-significant variables according to the effect of removal on the model significance.

\section{Results}

We found significant levels of intraspecific variation in architectural traits in $M$. albicans. As expected, plant height increased with increased habitat complexity. Plants growing in $\mathrm{CD}$ were 1.5-fold taller than plants in $\mathrm{CE}$ and 3-fold higher than plants in CS (Table 1). Individuals growing in $\mathrm{CD}$ also showed higher architectural complexity than plants in CS, but no significant difference in tertiary and quaternary shoot number was found between $\mathrm{CD}$ and CE plants (Table 1). In addition, plants growing in the CS were smaller and had fewer secondary, tertiary and quaternary shoots. However, the first shoot height showed no significant variation among these three physiognomies (Table 1).

Plants growing in CE produced more quaternary shoots than plants in the other two vegetation types (Table 1), and an increased production of quaternary shoot led to higher infructescence production (Table 2). Plant height and the number of tertiary and quaternary shoots were good predictors of total infructescence number, explaining $67.5 \%$ of the variation in the total infructescence number. The number of tertiary shoots and plant height were also significant in the minimum model for PD and TD infructescences, respectively (Table 2). However, they were poor predictors of total variation of PD and TD, explaining only $10 \%$ and $8 \%$ of their variation, respectively.

Except for the first shoot height, all RDPI values were highest for CS-CD plants. Interestingly, the distances between CS-CE plants were higher than those of CE-CD 
Table 1. Architectural traits and infructescence number of Miconia albicans along a soil fertility gradient in the Brazilian Cerrado.

\begin{tabular}{lccccc}
\hline \multicolumn{1}{c}{ Plant trait } & Campo sujo & Cerrado sensu stricto & Cerradão & Statistics & P \\
\hline Height $(\mathrm{cm})$ & $109.55 \pm 6.43^{\mathrm{a}}$ & $205.4 \pm 18.7^{\mathrm{b}}$ & $299.7 \pm 28.13^{\mathrm{c}}$ & 30.52 & $<0.0001$ \\
Height of first shoot $(\mathrm{cm})$ & $48.7 \pm 4.31$ & $42.9 \pm 5.39$ & $47.05 \pm 4.52$ & 0.39 & 0.68 \\
Secondary shoot number & $5.95 \pm 0.68^{\mathrm{a}}$ & $13.5 \pm 1.21^{\mathrm{b}}$ & $17.65 \pm 1.72^{\mathrm{c}}$ & 28.89 & $<0.0001$ \\
Tertiary shoot number & $8.5 \pm 1.37^{\mathrm{a}}$ & $22.35 \pm 2.54^{\mathrm{b}}$ & $24.45 \pm 3.89^{\mathrm{b}}$ & 9.65 & $<0.0001$ \\
Quaternary shoot number & $3.45 \pm 1.01^{\mathrm{a}}$ & $25.05 \pm 5.58^{\mathrm{b}}$ & $18.7 \pm 3.92^{\mathrm{c}}$ & 19.18 & $<0.0001$ \\
Infrutescence number & $8.45 \pm 1.55^{\mathrm{a}}$ & $25.8 \pm 3.47^{\mathrm{b}}$ & $13.3 \pm 2.48^{\mathrm{a}}$ & 16.82 & $<0.0001$ \\
\hline
\end{tabular}

Means $( \pm$ SD) followed by different letters are statistically different $(\alpha=0.05)$. Plant traits in bold denote data analysed by Kruskal-Wallis, in which W-value corresponds to F-value for ANOVA.

Table 2. Minimum model for predicting infructescence number in Miconia albicans. Architectural variables were logtransformed and the $\mathrm{y}$-variable is total infrutescence number (A), partially damaged infructescences (B), or totally damaged infructescences $(\mathrm{C})$.

\begin{tabular}{llcrrr}
\hline & \multicolumn{1}{c}{ Effect } & Coefficient & SE & t & P \\
\hline (A) & Constant & 1.150 & 0.442 & 2.601 & 0.013 \\
& Height & -0.492 & 0.212 & -2.326 & 0.025 \\
& Tertiary shoot number & 0.643 & 0.233 & 2.755 & 0.009 \\
& Quaternary shoot number & 0.296 & 0.120 & 2.456 & 0.018 \\
(B) & Constant & 1.957 & 11.486 & 0.170 & 0.865 \\
& Tertiary shoot number & 24.195 & 9.309 & 2.599 & 0.012 \\
(C) & Constant & 143.786 & 39.581 & 3.633 & 0.001 \\
& Height & -41.557 & 17.522 & -2.372 & 0.021 \\
\hline
\end{tabular}

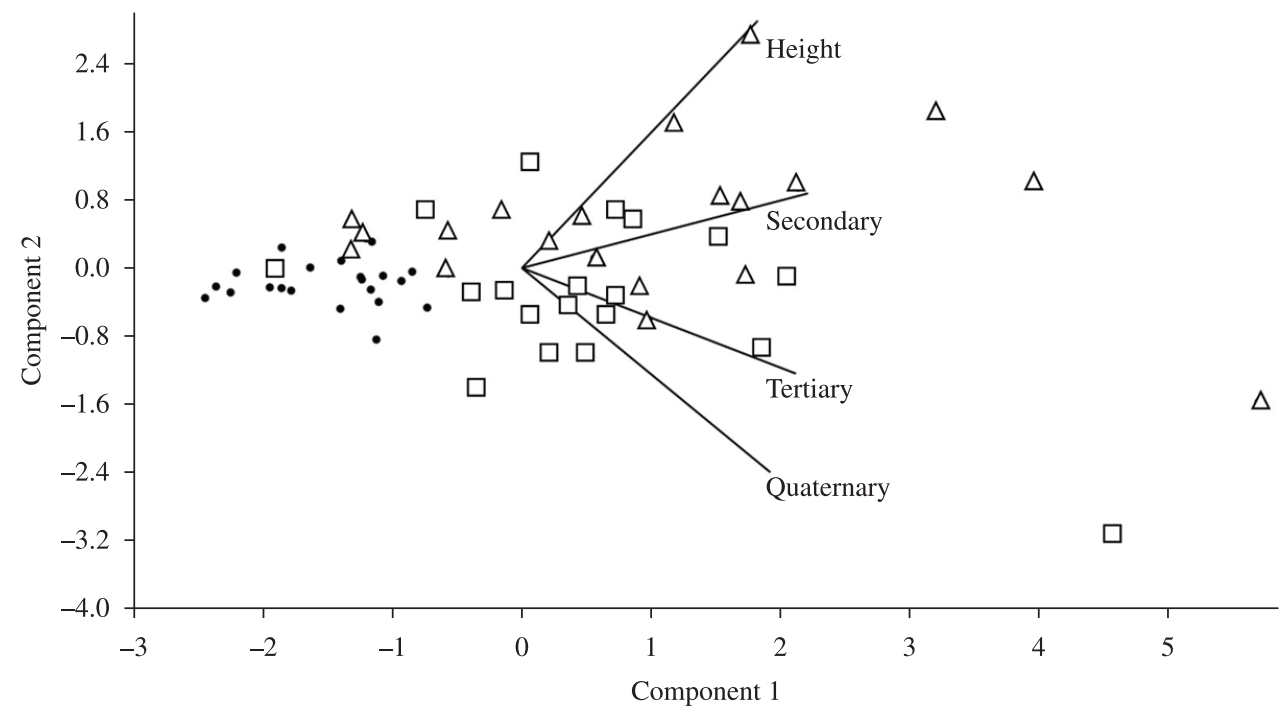

Figure 1. Biplot representation of the trait scores on the first two axes of the principal component analysis (PCA) of architectural parameters of Miconia albicans occurring in three Cerrado physiognomies. Filled circles: campo sujo, squares: cerrado sensu stricto, triangles: cerradão.

plants, indicating that $\mathrm{CE}$ plants were more similar to $\mathrm{CD}$ plants than to CS plants (Table 3). Similar patterns were obtained when multivariate analyses were employed. The PCA showed a strong overlap between CE and CD plants, whereas CS plants showed a relatively cohesive group (Figure 1). The two first axes of the PCA explained $91.8 \%$ of total variance. All variables were positively correlated with the PC1. The total number of tertiary and quaternary shoots was negatively correlated with PC2 (Table 4).

Nematode-induced galls accounted for fruit destruction in $76.5 \%$ of infructescences across physiognomies (Table 5), but their incidence was poorly related to architectural 
Table 3. Values of RDPI (relative distance plasticity index) of architectural parameters for Miconia albicans found along a soil fertility gradient in the Brazilian Cerrado. CS: campo sujo; CE: cerrado sensu stricto; and CD: cerradão.

\begin{tabular}{lccc}
\hline Architectural parameter & CS-CE & CE-CD & CS-CD \\
\hline Height $(\mathrm{cm})$ & 0.19 & 0.07 & 0.31 \\
Height of first shoot & 0.08 & 0.11 & 0.02 \\
Secondary shoot number & 0.21 & 0.02 & 0.33 \\
Tertiary shoot number & 0.21 & 0.01 & 0.31 \\
Quaternary shoot number & 0.17 & 0.12 & 0.23 \\
\hline
\end{tabular}

Table 4. Principal components (PC1) and (PC2) obtained from the matrix of correlation of architectural parameters for Miconia albicans in three Cerrado physiognomies.

\begin{tabular}{lcc}
\hline Architectural parameter & PC1 & PC2 \\
\hline Height $(\mathrm{cm})$ & 0.45 & 0.72 \\
Secondary shoot number & 0.54 & 0.22 \\
Tertiary shoot number & 0.52 & -0.31 \\
Quaternary shoot number & 0.47 & -0.59 \\
Variance explained $(\%)$ & 74.4 & 17.4 \\
\hline
\end{tabular}

Table 5. Frequency of healthy, partially damaged, and totally damaged infructescences of Miconia albicans in three physiognomies of Cerrado in southeastern Brazil. Numbers in parentheses refer to percentages.

\begin{tabular}{lcccc}
\hline \multicolumn{1}{c}{ Physiognomy } & Healthy & Partially damaged & Totally damaged & Total \\
\hline Campo sujo & $13(7.6)$ & $13(7.6)$ & $143(85.7)$ & 169 \\
Cerrado sensu stricto & $107(20.7)$ & $205(39.7)$ & $204(39.5)$ & 516 \\
Cerradão & $103(38.7)$ & $100(37.6)$ & $63(23.3)$ & 266 \\
\hline
\end{tabular}

variables (Table 2). The highest infestation levels were found in CS, and despite lower levels of infestation in $\mathrm{CD}$, more healthy fruits were produced in CE (Table 5).

\section{Discussion}

Cerrado species growing in distinct physiognomies exhibit strong variation in morphological, anatomical and physiological traits. The strong trait-environment correlation shown here for M. albicans is in accordance with the current ecophysiological theoretical framework. Plants growing in shaded physiognomies often show traits associated with light capture, whereas plants growing in open physiognomies exhibit traits related to water economy (Pedroso et al., 2010; Rossatto and Kolb, 2010; Bedetti et al., 2011). With regards plant architecture, one could expect plants from shaded habitats to be taller and present higher branching patterns. These sets of traits are related to resource acquisition and foraging for light (Pearcy et al., 2004). On the other hand, plants from open habitats are expected to be smaller and to produce less lateral shoots. Nevertheless, in addition to modifications related to light and water acquisition, soil fertility may also play a role in changes of plant size and architectural complexity (Chen et al., 2010). Therefore, careful experimental studies are needed to isolate the contribution of each of these environmental factors to explain plant trait variation across ecological gradients.

A remarkable finding of this study is that CD plants did not show higher architectural complexity or performance compared to those in CE, as initially expected. In addition to the architectural traits studied here, leaf and functional traits are more similar between CD and CE plants (Bedetti et al., 2011). The higher similarity between $C D$ and CE plants suggests the existence of physiological limitations in the expression of optimum phenotype under shaded conditions.
Constraints in the expression of leaf functional traits in CD plants may decrease carbon fixation (Bedetti et al., 2011). Thus, less energy is available for allocation to lateral growth and shoot production. Moreover, higher herbivory by leaf-chewing insects on CD plants (personal observation) can prevent plants from expressing optimum phenotype (Valladares et al., 2007). We argue that the costs for the expression of architectural traits related to resource acquisition overrides any potential positive effects plants may derive from higher soil fertility at CD (Meyer and Root, 1983).

The low apical dominance, high branching frequency, and shoot elongation shown here, along with the large leaf area, low SLA, and low lamina thickness of CD plants (Bedetti et al., 2011) characterise the shade tolerance syndrome (Valladares and Niinemets 2008). Under low light conditions, plants often allocate limited photosynthates to improve survival at the expense of resource allocation to growth and reproduction. In agreement with that, our data suggest that the observed reduced expression of architectural traits under shaded conditions may constrain plant performance. In this case, the reduced production of higher-order shoots in CD plants (strong determinants of infructescence production) compared to CE plants supports the idea that plants under shade show limited reproductive output (Bedetti et al., 2011).

Our data indicate a pervasive occurrence of nematode galls in a native Cerrado species. In contrast to insect galls, few ecological studies have addressed incidence of nematode galls in native species in the Neotropics. Although it seems premature to conclude that nematode-induced galls pose significant losses to plant performance, a consensus is emerging that nematode attack negatively affects plant performance (Seixas et al., 2004a, b; Santos et al., 2012; Viana et al., 2013). However, we still lack unequivocal quantitative data of the impact of nematode galls on plant 
performance. The infestation levels of Ditylenchus galls found here far exceed those reported for other Miconia species (Seixas et al., 2004a, b). Nematode galls on Miconia species are likely to decrease plant performance through photosynthate drainage and direct destruction of reproductive structures (Santos et al., 2012; Viana et al., 2013). As a result, nematode infestation may limit the expression of optimum plant phenotype, with the potential to drive the evolution of plant defensive traits (Agrawal, 2001).

Nematode species infecting above-ground plant parts must be able to move quickly within thin and often transient watery foliar surfaces (Robinson, 2002). Therefore, one would expect higher infestation levels under shady and humid CD habitats. Contrary to that, however, we found a higher density of totally destroyed infructescences in CS plants. Ditylenchus gall density is positively correlated with host-density (Viana et al., 2013), probably because infective stages typically must find roots or stems emerging from the soil to ascend foliage (Robinson, 2002). Therefore, plant density, rather than plant architecture, may be a better predictor of infestation levels of Ditylenchus galls in $M$. albicans.

The data reported here have important implications for our understanding of plant ecology in heterogeneous environments. We have shown a great level of intraspecific variation in plant architecture in a Neotropical species, and suggest that intraspecific variation may help plants to colonize heterogeneous habitats, such as tropical savannas. Furthermore, plant architecture and fruit production substantially affect the abundance and the diversity of insect herbivores and of their natural enemies (Lawton 1983; Casas and Djemai, 2002). It also affects fruit removal rates by frugivores (Christianini and Oliveira, 2009). Therefore, changes in plant architecture are expected to have important consequences across higher trophic levels. Future studies linking trait variation with plant demography are needed for a better understanding of the implications of our findings, and to refine predictions regarding population-level responses to heterogeneous habitats in a context of global climate change.

Acknowledgements - The Instituto Chico Mendes/Estação Ecológica de Pirapitinga provided logistical support. Financial support was provided by PIBIC/UNA.

\section{References}

AGRAWAL, AA., 2001. Phenotypic plasticity in the interactions and evolution of species. Science, vol. 294, p. 321-326. http:// dx.doi.org/10.1126/science.1060701

BARTHELEMY, D. and CARAGLIO, Y., 2007. Plant architecture: a dynamic, multilevel and comprehensive approach to plant form, structure and ontogeny. Annals of Botany, vol. 99, p. 375-407. http://dx.doi.org/10.1093/aob/mcl260

BEDETTI, CS., AGUIAR, DB., JANNUZZI, MC., MOURA, MZD. and SILVEIRA, FAO., 2011. Abiotic factors modulate phenotypic plasticity in an apomictic shrub [Miconia albicans (SW.) Triana] along a soil fertility gradient in a Neotropical savanna. Australian Journal of Botany, vol. 59, p. 274-282. http:// dx.doi.org/10.1071/BT10275

CASAS, J. and DJEMAI, I., 2002. Plant canopy architecture and multitrophic interactions. In TSCHARNKE, T. and HAWKINS, B. (Eds.). Multitrophic interactions. Cambridge: Cambridge University Press. p. 174-196. http://dx.doi.org/10.1017/CBO9780511542190.008

CHEN, FS., ZENG, DH., FAHEY, TJ., YAO, CY. and YU, ZY., 2010. Response of leaf anatomy of Chenopodium acuminatum to soil resource availability in a semi-arid grassland. Plant Ecology, vol. 209, p. 375-82. http://dx.doi.org/10.1007/s11258-010-9778-x

CHRISTIANINI, AV. and OLIVEIRA, PS., 2009. The relevance of ants as seed rescuers of a primarily bird-dispersed tree in the Neotropical cerrado savanna. Oecologia, vol. 160, p. 735-745. http://dx.doi.org/10.1007/s00442-009-1349-2

CUI, XY., TANG, YH., GU, S., SEIICHI, N., SHI, S. and ZHAO, X., 2003. Photosynthetic depression in relation to plant architecture in two alpine herbaceous species. Environmental and Experimental Botany, vol. 50, p. 125-35. http://dx.doi.org/10.1016/ S0098-8472(03)00018-2

GOLDENBERG, R., 2004. O gênero Miconia (Melastomataceae) no estado do Paraná. Acta Botanica Brasilica, vol. 18, p. 927-947. http://dx.doi.org/10.1590/S0102-33062004000400024

GOLDENBERG, R. and SHEPHERD, GJ., 1998. Studies on the reproductive biology of Melastomataceae in cerrado vegetation. Plant Systematics and Evolution, vol. 211, p. 13-29. http://dx.doi. org/10.1007/BF00984909

GRIME, JP. and MacKEY, JML., 2002. The role of plasticity in resource capture by plants. Evolutionary Ecology, vol. 16, p. 299307. http://dx.doi.org/10.1023/A:1019640813676

HALLGRIMSON, B. and HALL, BK., 2005. Variation, a central concept in biology. Academic Press.

LAWTON, JH., 1983. Plant architecture and the diversity of phytophagous insects. Annual Review of Entomology, vol. 28, p. 23-29. http://dx.doi.org/10.1146/annurev.en.28.010183.000323

MENDONÇA, RC., FELFILI, JM., WALTER, BMT., SILVA JUNIOR, MC., REZENDE, AV., FILGUEIRAS, TS., NOGUEIRA, PE. and FAGG, CW., 2008. Flora Vascular do bioma Cerrado: checklist com 12.356 espécies. In SANO, SM., ALMEIDA, SP. and RIBEIRO, JF. (Eds.). Cerrado: ecologia e flora. Brasília: Embrapa Cerrados. p. 421-1279.

MEYER, GA. and ROOT, RB., 1983. Effects of herbivorous insects and soil fertility on reproductive of goldenrod. Ecology, vol. 74, p. 1117-1128.

OLIVEIRA-FILHO, AT. and RATTER, JA., 2002. Vegetation physiognomies and woody flora of the cerrado biome. In OLIVEIRA, PS. and MARQUIS, RJ. The Cerrados of Brazil: ecology and natural history of a neotropical savanna. New York: Columbia University Press. p. 91-20

OLIVEIRA, RDL., SANTIN, AM., SENI, DJ., DIETRICH, A., SALAZAR, LA., SUBBOTIN, SA., MUNDO-OCAMPO, M., GOLDENBERG, R. and BARRETO, RW., 2013. Ditylenchus gallaeformans sp. n. (Tylenchida: Anguinidae) a neotropical nematode with biocontrol potential against weedy Melastomataceae. Nematology, vol. 15, p. 179-196. http://dx.doi.org/10.1163/1568541100002670

PEARCY, RW., VALLADARES, F., WRIGHT, SJ. and PAULIS, EL., 2004. A functional analysis of the crown architecture of tropical forest Psycothria species: do species vary in light capture 
efficiency and consequently in carbon gain and growth? Oecologia, vol. 139, p. 163-177. http://dx.doi.org/10.1007/s00442-004-1496-4

PEDROSO, HL., ROCHA-FILHO, LC. and LOMÔNACO DE PAULA, C., 2010. Variación fenotíca de plantas del Cerrado (Sabana brasileña) frente a la heterogeneidad ambiental. Ecosistemas, vol. 19, p. 1-12.

PIL, MW., BOEGER, MRT., PIE, M., GOLDENBERG, R., OSTRENSKY, A. and BOEGER, WA., 2012. Testing hypotheses for morphological differences among populations of Miconia sellowiana (Melastomataceae) in southern Brazil. Acta Scientiarum. Biological Sciences, vol. 34, p. 85-90.

RENNER, SS., 1989. A survey of reproductive biology in Neotropical Melastomataceae and Memecylaceae. Annals of the Missouri Botanical Garden, vol. 76, p. 496-518. http://dx.doi. org/10.2307/2399497

ROBINSON, AF., 2002. Soil and plant interaction's impact on plant-parasitic nematode host finding and recognition. In LEWIS, EE., CAMPBELL, JF., SUKHDEO, MVVK. (Eds.). The behavioral ecology of parasites. Wallingford: CAB International. p. 89-110.

ROSSATTO, DR. and KOLB, RM., 2010. Gochnatia polymorpha (Less.) Cabrera (Asteraceae) changes in leaf structure due to differences in light and edaphic conditions. Acta Botanica Brasilica, vol. 24, p. 605-612. http://dx.doi.org/10.1590/S010233062010000300002

SALAZAR, A., GOLDSTEIN, G., FRANCO, AC. and MIRALLESWILHELM, F. 2012. Seed limitation of woody plants in Neotropical savanas. Plant Ecology, vol. 213, p. 273-287. http://dx.doi. org/10.1007/s11258-011-9973-4

SANTOS, JC., SANTOS, CIR., CARES, JE. and ALMEIDACORTEZ, JA., 2012. Impact of nematode-induced galls on Miconia prasina (Sw.) DC (Melastomataceae) traits in the Atlantic forest of northeastern Brazil. Journal of Plant Interactions, vol. 7, no. 3, p. 1-7

SARLIKIOTI, V., DE VISSER, PHB. and MARCELIS, LFM., 2011. Exploring the spatial distribution of light interception and photosynthesis of canopies by means of a functional-structural plant model. Annals of Botany, vol. 107, p. 875-883. http://dx.doi. org/10.1093/aob/mcr006

SEIXAS, CDS., BARRETO, RW., FREITAS, LG., MAFFIA, LA. and MONTEIRO, FT., 2004a. Ditylenchus drepanocercus, a potential biological control agent for Miconia calvescens (Melastomataceae), host-specificity and epidemiology. Biological Control, vol. 31, p. 29-37. http://dx.doi.org/10.1016/j.biocontrol.2004.05.002

SEIXAS, CDS., BARRETO, RW., FREITAS, LG., MONTEIRO, FT. and OLIVEIRA, RDL., 2004b. Ditylenchus drepanocercus rediscovered in the Neotropics causing angular leaf spots on Miconia calvescens. Journal of Nematology, vol. 36, p. 481-486.

SILVEIRA, FAO., MAFIA, PO., LEMOS-FILHO, JP. and FERNANDES, GW. 2012. Species-specific outcomes of avian gut passage on germination of melastome seeds. Plant Ecology and Evolution, vol. 145, p. 350-355.

SOMAVILLA, NS. and GRACIANO-RIBEIRO, D., 2011. Análise comparativa da anatomia foliar de Melastomataceae em ambiente de vereda e cerrado sensu stricto. Acta Botanica Brasilica, vol. 25, p. 764-775. http://dx.doi.org/10.1590/S0102-33062011000400004

SUSSEX, IM. and KERK, NM., 2001. The evolution of plant architecture. Current Opinion in Plant Biology, vol. 4, p. 33-37. http://dx.doi.org/10.1016/S1369-5266(00)00132-1

VALLADARES, F., SANCHEZ-GOMES, D. and ZAVALA, MA., 2006. Quantitative estimation of phenotypic plasticity. Journal of Ecology, vol. 94, p. 1103-116. http://dx.doi.org/10.1111/j.13652745.2006.01176.x

VALLADARES, F., GIANOLI, E. and GÓMEZ, JM., 2007. Ecological limits to plant phenotypic plasticity. New Phytologist, vol. 176, p. 749-763. http://dx.doi.org/10.1111/j.14698137.2007.02275.x

VALLADARES, F. and NIINEMETS, U., 2007. The architecture of plant crowns, from design rules to light capture and performance. In PUGNAIRE, F. and VALLADARES, F. Functional plant ecology. Boca Raton: CRC publishers. p. 101-150. http://dx.doi. org/10.1201/9781420007626.ch4

-, 2008. Shade tolerance, a key plant feature of complex nature and consequences. Annual Review of Ecology, Evolution and Systematics, vol. 39, p. 237-257. http://dx.doi.org/10.1146/ annurev.ecolsys.39.110707.173506

VIANA, LR., SILVEIRA, FAO., SANTOS, JC., ROSA, LH., CARES, JE., CAFÉ-FILHO, AC. and FERNANDES, GW., 2013. Nematode-induced galls in Miconia albicans: effect of host plant density and correlations with performance. Plant Species Biology, vol. 28 , no. 1 , p. 63-69.

WEINER, J., 2004. Allocation, plasticity and allometry in plants. Perspectives in Plant Ecology, Evolution and Systematics, vol. 6, p. 207-215. http://dx.doi.org/10.1078/1433-8319-00083 